Brazilian Journal of Political Economy, vol. 41, $n^{\circ}$ 2, pp. 314-332, April-June/2021

\title{
Modern Money Theory: rise in the international scenario and recent debate in Brazil
}

\author{
Modern Money Theory: ascensão no cenário \\ internacional e debate no Brasil
}

SIMONE DEOS*

OLÍVIA BULLIO MATTOS**

FERNANDA ULTREMARE ${ }^{\mathrm{x}}$

ANA ROSA RIBEIRO DE MENDONÇA ${ }^{\mathrm{xx}}$

RESUMO: O presente artigo tem duplo objetivo: apresentar o núcleo da Modern Money Theory e sua recente ascensão no debate brasileiro, a qual se deu a partir da publicação dos artigos de Lara Resende na imprensa, em 2019, seguidos pela publicação de seu livro em 2020. Para tanto, o trabalho está dividido em três seções, além da introdução e de considerações finais. Na primeira, apresentamos o core da MMT. Na segunda seção, algumas das críticas ortodoxas e heterodoxas enviadas ao MMT são discutidas. Na terceira seção, apresentamos o espraiamento das ideias da MMT no Brasil, observando o contexto macroeconômico e político peculiar no qual isso se deu. Uma crítica às contribuições de Lara Resende numa chave de “economia política” é feita na conclusão.

PALAVRAS-CHAVES: Macroeconomia; economia monetária; Modern Money Theory.

ABSTRACT: This paper has a twofold purpose. The first one is to present the core ideas of MMT. The second one is to explain its recent rise in Brazil after the publication of Andre Lara Resende's articles in the press in 2019 and a book in 2020. In order to do that, the paper is organized as follows. After the introduction, the first session presents the core ideas of MMT: i) chartal money, or tax driven money; ii) functional finance; iii) Minskyan financial fragility; iv) sectoral balances approach; v) employer of last resort. The second session

\footnotetext{
* Professor,Universidade Estadual de Campinas, Campinas/SP, Brasil. E-mail: simonededeos@gmail.com. Orcid: https://orcid.org/0000-0003-1134-0871.

** Assistant professor, St. Francis College, New York/NY, EUA. E-mail: obulliomattos@sfc.edu. Orcid: https://orcid.org/0000-0001-8797-071X.

x Assistant professor, Universidade Federal do Rio Grande do Sul, Porto Alegre/RS, Brasil. E-mail: feultremare@gmail.com. Orcid: https://orcid.org/0000-0003-4444-0959.

xx Professor, Universidade Estadual de Campinas, Campinas/SP, Brasil. E-mail: anarosa.r.mendonca@ gmail.com. Orcid: https://orcid.org/0000-0003-3521-188X. Submitted: 6/February/2020; Approved: 9/ August/2020.
} 
presents some critiques MMT has received both from the orthodox and the heterodox sides at the international level. The third section discusses the particular way in which MMT's ideas have recently arrived in Brazil, considering peculiarities of the Brazilian economic debate and political scenario. The final session brings back the main ideas presented in the paper and raises critics to Lara Resende's contributions from a political economy perspective. KEYWORDS: Macroeconomics; monetary economics; Modern Money Theory.

JEL Classification: E12; E60; E66.

\section{INTRODUCTION}

The economic debate in Brazil has been recently shaken by Modern Money Theory's (MMT) ideas. Until then, MMT was only known and discussed in the academic arena by a few economists. But a series of pieces written by André Lara Resende from March to August of 2019 in the main business newspaper in Brazil - Valor Econômico - moved the debate beyond academia. In this set of articles, that later became part of his new book (Resende, 2020), Lara Resende presented the core ideas of MMT - money as a unit of account and money as debt issued by the State, which is accepted because it is needed in order to pay taxes - when the debt is then redeemed. Being money a unit of account and not a "thing" with intrinsic value, the State has no financial constraint, only a "reality constraint."

André Lara Resende, which has graduated in Economics at Pontifical Catholic University of Rio de Janeiro (PUC-RJ) and got his PhD at MIT, is a well-known economist in Brazil. In the 1980s, when the country faced a period of extremely high inflation, he was part of a group of economists that developed the idea that inflation has a major inertia component - in what became known as the "inertial inflation theory" ${ }^{1}$, challenging mainstream's approach and policies to deal with inflation at that time. In 1986, Lara Resende was appointed Director for Public Debt and Monetary Policy of the Brazilian Central Bank. In 1994, he became a member of the team responsible for the Real Plan that aimed - and succeeded - to fight high inflation in Brazil. Based on the assumption that inflation was inertial, it would be necessary to peg the national currency to a foreign one. In 1998, he was appointed President of the Brazilian National Development Bank - BNDES. After leaving BNDES, Lara Resende considered himself a "retired economist" (Resende, 2020). But, according to him, things changed after the 2008 crisis and from 2013 to 2020 Lara Resende published four books. The last one - Consenso e contrassenso: por uma Economia não dogmática - is the one in which he embraces MMT's ideas.

Only recently introduced in the Brazilian public debate by Lara Resende, MMT results from the work that a group of heterodox economists has been doing for

\footnotetext{
${ }^{1}$ Resende, André Lara; Arida, Pérsio. (1985). Inflação inercial e reforma monetária no Brasil. Texto para Discussão n. 85, Departamento de Economia. PUC-RJ.
} 
approximately two decades, being Randall Wray (Wray, 1998, 2003, 2012) one of the leaders. These economists gained public attention - probably for the first time - when the Global Financial Crisis (GFC) erupted, and the ideas of Hyman Minsky - which is an important theoretical reference among this group - gained momentum. Also, MMT's economists were pioneers in criticizing the Euro currency, for them an idiosyncratic creation in which countries give up their own currency and monetary sovereignty. And again, when the Euro crisis erupted and the whole Euro project started to be questioned, MMT's authors regained attention.

At the international level and especially in the US, there has been a growing perception that mainstream macroeconomic theory is facing a crisis (Blanchard, 2010, 2018; Blanchard and Summers, 2018; Stiglitz, 2018), not only for the failure of its forecasts - not anticipating the GFC being the supreme case, since until the last minute the leading mainstream macroeconomists didn't see it coming - but also because of its inefficient policy proposals. In a macroeconomic scenario of increased public indebtedness and enlarged balance sheet of central banks - results of the post 2008 crisis' rescue policies - mainstream theory did not prescribe expansionary fiscal policies in order to stimulate the economy. So, it would be up to monetary policy to boost the economies. And although monetary authorities have been innovating since the GFC with interest rates at very low levels and even reaching negative rates, the impacts in real economy have been, at best, not sufficient. According to Blanchard and Summers (2017), taking into consideration the limits of monetary policy, fiscal policy becomes important, contrarily to the mainstream macro model.

Thus, in the aftermath of the GFC, macroeconomic models - synthetic representations of reality - as well as policy prescriptions coming from them, started to be questioned:

The crisis was not triggered primarily by macroeconomic policy. But it has exposed flaws in the pre-crisis policy framework, forced policymakers to explore new policies during the crisis, and forces us to think about the architecture of post-crisis macroeconomic policy (Blanchard, 2010, 16).

In this context, theoretical issues which have always been crucial from a Keynesian-Minskyan perspective, and were not relevant to mainstream macroeconomics up to that moment - such as bank money and finance, endogenous financial fragility, as well as the key role of fiscal policy and financial regulation -were brought into the picture, but in a somewhat clumsy way.

It was in this environment of increasing dissatisfaction with mainstream economics that MMT crossed the borders of the academic debate and started to be discussed in important media outlets, including newspapers, all over the world. Contributing to this was the fact that important members of the left side of Democratic Party in the US have explicitly assumed that MMT's ideas are behind their 
policy propositions. Also, some MMT's theoretical founders are very active not only in academic outlets, but also in the web².

This paper has a twofold purpose. The first one is to present the core ideas of MMT. The second is to explain its recent rise in Brazil. In order to do that, the paper is organized as follows. After the introduction, the first session presents the core ideas of MMT: i) chartal money, or tax driven money; ii) functional finance; iii) Minskyan financial fragility; iv) sectoral balances approach; v) employer of last resort. Some of the critiques MMT has received both from the orthodox and the heterodox sides at the international level are discussed in the second section. The third one presents the particular way in which MMT's ideas have recently arrived in Brazil, considering peculiarities of the Brazilian economic debate and political scenario. The final session brings back the main ideas presented in the paper and raises critics to Lara Resende's contributions from a political economy perspective.

\section{WHAT IS MODERN MONEY THEORY?}

The so-called Modern Money Theory (MMT) started to take shape in 1998 when the book Understanding Modern Money, written by Randall Wray, was published. The term "modern money" - ironically employed by the authors in a reference to Keynes - was related to the way monetary systems have been working in the last 4,000 years, marked by the presence of state money (Wray, 2012). In the recent years, MMT gained prominence in the economic debate in the United States as Stephanie Kelton - now Professor at Stony Brook University and one of the most important defenders of MMT ideas - became the economic adviser to the US Senator Bernie Sanders' campaign for the Democratic Party primaries in 2016, and again in 2020. That prominence increased with the support of Alexandria OcasioCortez (AOC) - Congresswoman elected by the State of New York in 2018 - to MMT's ideas in order to implement progressive policy proposals, such as free college, Medicare for all, federal jobs guarantee, and the Green New Deal. "She said the idea, which holds that the government doesn't need to balance the budget and that budget surpluses actually hurt the economy, 'absolutely' needed to be 'a larger part of our conversation" ${ }^{3}$.

Considered by its founders as part of the Post-Keynesian school, MMT incorporates other theoretical lines within the heterodox field, such as the Institutionalists (Veblen), the Chartalists (Knapp, Innes), Functional Finances (Abba Lerner) and the Sectoral Balances (Wynne Godley). MMT stems from heterodox assumptions in order to: 1) describe the way capitalist economies work, with monetary

\footnotetext{
2 See http://bilbo.economicoutlook.net/blog/ and http://neweconomicperspectives.org/cate gory/l-randall-wray.

${ }^{3}$ See https://www.businessinsider.com/alexandria-ocasio-cortez-ommt-modern-monetary-theory-howpay-for-policies-2019-1.
} 
and fiscal arrangements at its center ${ }^{4}$; and to 2 ) prescribe public policies to avoid financial instability and ensure that full employment is achieved.

The State plays a fundamental role for MMT. Besides the discussion of the historical evolution of money and its intrinsic relationship with the State, MMT explains: 1) how public spending is actually implemented; 2) the relationship between the Central Bank and the National Treasury; and 3) how State money is created. Starting with the understanding of the nature of money, MMT advocates refute the thesis that money was "born" from barter, as there are no historical evidences of the existence of barter-based economies. The modern money emerged in fact as a unit of account, which is its primary function. The monetary relations are anchored in State sovereignty and monopoly. According to Keynes, in his Treatise on Money, the State:

claims the right to determine and declare what thing corresponds to the name, and to vary its declaration from time to time - when, that is to say, it claims the right to re-edit the dictionary. This right is claimed by all modern States and has been so claimed for some four thousand years at least. (Keynes, 1971, 4)

Therefore, money and the State are inseparable. The State, by imposing obligations in the form of taxes, which have to be paid in what (the thing) it has termed as money, and by issuing the thing, guarantees its demand. This money is a State debt, created whenever the State makes an expense and redeemed whenever an agent makes a payment to the State.

This approach, called by Wray (1998) as "tax-driven money" or as chartalist view of money - based on Knapp -, has several implications for macroeconomic policy. Given that the function of taxes is not financing public expenditures, but to withdraw money from circulation ${ }^{5}$, the State necessarily has to spend first in order to guarantee the money needed by economic agents to pay taxes imposed to them. In the end, all public spending means a deficit. In other words, a public deficit measured over a certain period of time means nothing more than that the government is putting more money into circulation than it is 'withdrawing' through taxes. Therefore, public bonds, for their turn, don't finance government spending, being a type of public debt that, unlike money itself, yields interest rates. In 'modern' times, they are also used as instruments of monetary policy. That said, the only restrictions faced by the State on the issuance of money are self-imposed, political in nature and expressed in the form of legal rules.

\footnotetext{
${ }^{4}$ It is important to highlight that it is impossible for a country to "follow" MMT principles - once MMT is exactly a description of modern monetary economies.

${ }^{5}$ Despite taxes not having the function of financing public expenditures, they should be nonetheless imposed. Taxes are important because they make the economic system fairer, creating an incentive-anddisincentive system for certain economic sectors and activities and avoiding excessive income concentration.
} 
A country which issues its own sovereign currency does not have financial restrictions; it cannot be insolvent in its own currency. MMT supporters understand that a currency is sovereign when: i) government has the monopoly of money issuance that is the prevailing unit of account, i.e., it has legal tender; ii) it is fiat money or, in other words, there is nothing backing it, like metal or even a foreign currency; iii) the public debt is issued in the domestic currency; iv) the exchange rate regime is a floating one. If a country meets these conditions, it issues sovereign currency.

An important part of MMT literature focuses on countries with the highest degree of monetary sovereignty, such as the United States, the United Kingdom, Japan, and Australia. Notwithstanding, peripheral countries, which meet the above requirements, also have sovereign currency, although with lower degrees of freedom in the type of macroeconomic policies they can adopt. Thus, even for these countries, any debate involving prescriptions of "austerity" would be anchored in gold standard and commodity-based money fundamentals.

The balance sheets of economic sectors and the stock and flow analysis have a special role in MMT's analytical framework. Developed by Wynne Godley, the sectoral balances approach organizes the economy into three major sectors: domestic government, domestic private sector (households and businesses) and external sector. For the macroeconomic aggregates of a closed economy, the following is true:

\section{Private Sector Balance + Government Balance $=0$}

In the case of an open economy, we will have:

\section{Private Sector Balance + Government Balance + External Sector Balance $=0$}

This identity shows that it is impossible for the three sectors to have the same result (either deficit or surplus) at the same time. It also shows that the government result will always have the opposite sign of the private sector result (considered as the sum of the domestic private sector and the external sector). Therefore, "if one sector spends more than its income, at least one of the others must spend less than its income because for the economy as a whole, total spending must equal total receipts or income" (Mitchell, Wray and Watts, 2019, 14). In other words, if the government runs a deficit, the private sector's net position is necessarily of accumulation of financial wealth. One sector's savings means, logically, that the other sector is spending more than its income, i.e., it has a deficit. So, in the case of an open economy, we have:

\section{Domestic private sector surplus + External sector surplus = Government deficit}

The conduct of fiscal policy - the way the State makes its spending decisions and collects its receipts - is also emphasized by MMT. When the State spends - either paying its employees or the suppliers of goods and services it purchases - these 
expenditures are operationalized through the National Treasury (NT) account at the Central Bank (CB), which, in its turn, will credit bank reserves (created ex-nihilo by the $\mathrm{CB}$ ) in commercial banks' reserve accounts. Commercial banks will then credit their clients' checking accounts. Bank reserves are also created by other strictly monetary operations made by the Central Bank - such as open market securities purchases. In summary, reserves are created with both government (NT) spending on the purchase of goods and services and with Central Bank's monetary policy, but only the former, in fact, creates deposits and pumps aggregate demand. The inverse monetary operation, bond sales, made either by the Central Bank or the Treasury, drains reserves from the system. Both should be viewed in the same way, which reinforces the perception that bonds do not finance the public deficit. In short, government spending always creates reserves and deposits. The payments of taxes by the private sector destroy both.

The endogenous creation of bank money is a central point for MMT aligned with the Post-Keynesian structuralist version of the money supply. The idea is: commercial banks create money when they make the decision to grant an ex-nibilo loan by recording a credit on the asset side of their balance sheet and a deposit on the liability side. Only after deciding to lend and as a result creating a demand deposit, the bank will go the interbank market or to the Central Bank for the needed reserves. Banks do not lend reserves, nor do they lend deposits. Banks create money (but do not create reserves).

That said, the State money and other private IOUs - such as bank deposits give shape to a hierarchy of monetary instruments. The IOU issued by the State is always at the top, as it is considered the ultimate and most liquid means of payment; below it, the IOUs are ordered according to their convertibility into State money. The bank's IOU, for its turn, is just below the State money, as its convertibility to the State money is guaranteed by the direct access of banks to the Central Bank's resources.

The Functional Finance approach is another MMT pillar. Lerner's central argument is that the government should always make spending decisions when income and employment levels are low, i.e., the government expenditures should be compatible with full employment. Lerner's argument is thus contrary to "sound finance" and the idea that government should manage its accounts as if it were a family. For the author, the search for a balanced public budget would not be "functional" for the economy to reach full employment. According to Wray $(2012,194)$ :

The idea is pretty simple. A government that issues its own currency has the fiscal and monetary space to spend enough to get the economy to full employment and to set interest rate target where it wants [...] For a sovereign nation, 'affordability' is not an issue; it spends by crediting bank accounts with its own IOUs, something it can never run out of. If there is unemployed labor, government can always afford to hire it, and by definition unemployed labor is willing to work for money. 
MMT is strongly influenced by the ideas of Hyman Minsky, who in his 1986 book Stabilizing an Unstable Economy presented a theoretical framework that enabled the understanding of the endogenous credit cycle and financial fragility. Minsky's analysis, by showing the importance of liabilities for agents' spending decisions, paved the way for understanding crises as derived from economic agents' rational behavior - including - and maybe especially - banks' decisions - that endogenously increase financial fragility over the economy expansion phase (Gerioni and Deos, 2018). A crisis begins when the financing conditions change and economic agents in debt face difficulties to meet financial commitments assumed in the past or, more often, difficulties to refinance these commitments. As it gets harder to access the market for refinancing, those agents need to liquidate their positions ("sell position to make position") to get funds, which leads to a decrease in assets' prices. Therefore, the economy gets into a "debt deflation" process and only the Big Bank - as lender of last resort - and the Big Government - conducting an anti-cyclical fiscal policy - would be able to stop the deflationary spiral of the assets' prices. As a conclusion, one could say that relying on private investment and financing to lead economic growth can be a huge mistake, as the result tends to be a very unstable system.

In more recent debates, MMT has been mistakenly - and maybe deliberately - reduced to a theory that advocates for "unlimited state debt." This could not be further from the truth. What is highlighted by MMT is that the fear of deficit spending is irrational and should not be an impediment to achieving full employment (Wray, 2015).

That said and stemming from the perception that the economy does not tend to full employment and stability on its own, MMT proposes a policy of public spending for the pursuit of full employment. More specifically, the public policy prescription is the so-called "employer of last resort" based on Minsky's argument (2013) that the government should act similar to the 'Lender of Last Resort', but as an Employer of Last Resort - ELR, proposing a type of "bubble up" policy, in lieu of a "trickle down" policy. To Minsky, as it is to MMT proponents, this would have very clear and specific goals: to stabilize the economy and guarantee full employment (Minsky, 1986, 2013; Wray, 1998, 2015).

The ELR as a permanent policy would make the government budget strongly countercyclical, acting as a job supply buffer. On recessions, with workers moving from the private sector to the ELR program, government expenditures would increase. On expansions, the process would be reversed, and the private sector would absorb workers previously hired by the state (Wray, 2015). This would reduce inequality and increase financial and price stability. The government - acting to eliminate involuntary unemployment and setting, exogenously, the "marginal" price of labor - would reduce both the boom's inflationary pressure - dampening wage pressures from the growth on private employment - and the recession's deflationary pressure, setting a floor to wages as the economy slows down (Wray, 1998; Burgess and Mitchell, 1998). 


\section{CRITIQUES TO MMT IN INTERNATIONAL CONTEXT}

Although MMT has gained popularity among politicians and in the media, its theoretical foundations and policy proposals have received a lot of criticism in the academia, both in the mainstream and heterodox circles. On the mainstream side, MMT has got the attention of Gregory Mankiw, for example, one of the main exponents of the New Keynesian school and someone who still has a lot of influence in policymaking. In a paper presented at the AEA meeting in January 2020, he first tries to degrade MMT for been "developed in a small corner of academia" (Mankiw, 2020,1) and only rising to fame after being supported by AOC and Senator Bernie Sanders in the US. In order to discredit its theoretical foundation, Mankiw resorts to the same old quantity theory of money (QTM) critique: the excessive creation of money in the form of banking reserves which happens when government increases spending will eventually lead to a higher inflation. Being so, having the ability to create money would then have little worth.

Having stated that, Mankiw then takes a turn and connects MMT with the New Keynesian approach, citing the "Keynesian regime" possibility when the goods and labor markets face excess supply. In his words: "This logic brings me back to MMT. The conclusion that 'economies typically operate with spare productive capacity' can be interpreted as meaning that economies are usually in the Keynesian regime of generalized excess supply. In that sense, MMT is akin to New Keynesian analysis" (Mankiw, 2020, 6). What Mankiw fails to recognize is that for MMT the excess supply, especially in the labor market, is not due to any kind of wage rigidity (a central New Keynesian argument) that prevents economic variables to return to market-clearing levels, but to the lack of effective demand.

From the heterodox side, important and even harsh critiques have been made by Gerald Epstein (2019), Marc Lavoie (2013, 2019) and Tomas Palley (2015a, 2015b, 2019).

Epstein (2019) discusses some limits to MMT's approach, focusing on developing countries. For him, while MMT correctly identifies the causes of hyperinflation (coming from profound disruption like wars or other supply side issues, and not from excess demand or over-issuance of money), he does not agree that public debt levels are not a problem just because governments can never default in their own currency. For Epstein (2019), developing countries, even with flexible exchange rate regimes, are subjected to sudden stops in capital flows and exchange rate crises. With currency depreciation, private debt in foreign currency will be harder to be repaid, causing depressions. Note that this line of argument will be central to some of the critiques coming from the heterodox Brazilian economists, as we will see in the next section. What one can say about it is that MMT does not support opening up the capital account, once there would be consequences to the economy caused by the high volatility of exchange rates - in terms of inflationary pressures (passthrough effect) and in terms of pressure on agents holding debts denominated in foreign currency (currency-mismatch effect). But once the country opens up capital accounts, one has to notice also that, in reality, i) Central Banks do intervene in the 
markets in order to avoid excessive volatility; ii) Central Banks are always in charge of the monetary policy and keep total control over short term domestic interest rates, and iii) to implement an expansionary fiscal policy to react to the potential disruptive effects of the currency mismatch, the country actually does not need foreign currency.

According to Lavoie, the main contribution from MMT is to the field of monetary economics: a better understanding of the relationships between central banks and Treasuries (Lavoie, 2013, 2019). The author also highlights the role of MMT's ideas on fiscal policies after the 2008 financial crisis. The fact that MMT proponents are very active and vocal not only attracted the attention of social media and politicians, but also forced mainstreams macroeconomists and central bankers to react to their heterodox approaches. With the defense that the main constraints on government expenditures are not financial but rather self-imposed, MMT made room for expansionary fiscal policies. On the other side, Lavoie (2019) raises some concern on the statement that there are no financial constraints on government spending, even considering that there is an internal logic in the statement. What one can say about Lavoie's critique is that, besides it being friendly (relatively to other Post-Keynesian fellows), he still has to come to terms with this key point: do governments have financial constraints?

Palley (2015a, 2015b, 2019) on his turn draws some acid remarks to many MMT statements. For him, there is nothing new regarding MMT's monetary theory or macroeconomic policy, as old Keynesians already presented many of its propositions. But for Palley the most important thing is that MMT ignores the challenges of achieving non-inflationary full employment due to a lack of understanding the impacts of money-financed fiscal policy on inflation. For him, moneyfinanced fiscal policy can be used when the economy is away from full employment. Nonetheless, when the economy reaches that point, there would be inflationary pressure. So, regarding Palley's critique, one can say that he didn't get the point that, for MMT, government spending is always money-financed. Also, he disregards that ELR (or Job Guarantee) policy program comes exactly to allow a country to reach full employment before pressuring the price level. Needless to say that this is very different from the old Keynesian pump-priming policy.

\section{MODERN MONEY IN THE BRAZILIAN CONTEXT}

The last two decades have witnessed two very distinct movements for the Brazilian economy: on the one hand, more specifically between 2004 and 2010, there was economic growth with social inclusion. On the other, the deceleration of aggregate demand, resulting from a reorientation of economic policy, marked the country's entering into technical recession as early as 2014, with rising unemployment rate. Politics itself, in the broad sense, was at the center of the crossroads that marked the trajectory from the expansive cycle to the recessive adjustment.

Still hitting primary surplus targets, in a context of commodity boom, the first 
period was characterized by government spending directly stimulating aggregate demand. Along with policies to recover and boost wages, there were an expansion of investments by state-owned companies, increased social transfers linked to the real increase in the minimum wage, and growth in operating expenses. The political view that governments ought to stimulate the private sector reflected also in expansionary monetary policy. Interest rates were down with new credit facilities for consumption and the construction sector. The private sector responded with higher consumption and investment (Serrano and Summa, 2015, 2018).

However, from 2011 on a new strategy was put in place, changing the orientation of economic policy. The goal was shifting the leading role in driving growth to the private sector. Macroeconomic policy then focused on reducing interest rates and devaluing the exchange rate. Nonetheless, with private investment and exports already faltering, the most immediate result was the acceleration of inflation. In 2013, facing inflationary pressures, the Central Bank raised interest rates, disrupting the path of monetary easing. The stimulus tools chosen were tax exemptions along with public-private partnerships for public services and infrastructure. But without a significant increase in aggregate demand, private investment made little progress and the new strategy considerably reduced economic growth.

Yet, instead of serving as a warning about the private sector's inability to drive growth, the bad economic results served to cement the rhetoric that fiscal stimulus from the previous period had been excessive and caused a significant deterioration of public finances. The view from both 'markets' and a substantial part of economists was that the various government interventions worsened indicators for capital efficiency, and real wages growing above productivity compressed profits and thus the domestic saving rate. It was therefore necessary to promote an explicit fiscal contraction policy and to have public finances in "order". Only then the confidence of private investors would increase, and they would take on their role as the primary drivers for economic growth (Mesquita, 2014; Barbosa and Pessoa, 2014; Ipea, 2018). The pressure of this rhetoric was so strong that even the worsening in social indicators, the recurring decrease in consumption, and the contraction in employment meant nothing. More political space was opened to advance austerity policies.

The year of 2019 in Brazil began with the inauguration of President Jair Bolsonaro. From an economic perspective, the new government was promising to launch the deepest liberal experiment in the country's history. It is important to remember that the Brazilian GDP at the end of 2018 was below the level observed in 2014. In his opening speech, the Minister of Economy, Paulo Guedes, presented his diagnosis on the Brazilian economy:

"The lack of control over the expansion of public spending is the greatest of evils [...] It has been a continuous expansion of public spending in relation to GDP that has been uninterrupted for four decades. And we have experienced all possible financial dysfunctions as a result of this process: hyperinflation, external moratorium, foreign-exchange crises and finally, 
now we are breathing, apparently in the shadow of a tranquility, but it is a false one, because it is in the shadow of economic stagnation. So, a time comes when the phenomenon has to be faced and the time is now." (Guedes, 2019, 1-2, own translation)

In this difficult situation, he presented the 'good news': he and his team would have the remedy for this deep and persistent evil: a reform aimed at reducing the size of the State. In this neoliberal journey the first and greatest challenge to be faced would be the pension reform. Also, according to Guedes (2019), the second pillar of the reform would be privatization, and the third simplifying, reducing and finally eliminating taxes.

If the new President, due to his political trajectory, created some doubts and concerns among the national elite and the so-called "mainstream media", his economic team was hailed as the guarantor of governability, as it would hold the correct diagnostics about the country's main problems, and be brave enough to pursue the solutions.

It was in this context, of a media massacre in which the need for fiscal balance and the reduction of public spending were ceaselessly advertised, that Lara Resende's articles in the Valor Econômico newspaper were published during the first half of 2019, having important repercussions and generating intense debate. Given his academic credentials and the several key positions he has occupied in governments in the past, his opinion always draws attention.

In "The Crisis of Macroeconomics", the first article in the series", Lara Resende presents what would be the core of the new macro approach and joins the economists who, internationally, declare the failure of conventional theory. He points out that in the United States this perception had already moved beyond the walls of academia and invaded politics and the mainstream media. The old ideas were finally dying, and the good news was that new ones were being born. For the author:

The new macroeconomics that begins to be outlined is capable of explaining phenomena that are incompatible with the old paradigm. This is the case, for example, of stubborn inflation below targets in advanced economies, even after an unusual increase in the monetary base. It allows us to understand how it is possible for the Japanese economy to carry a public debt above $200 \%$ of GDP, with interest close to zero, without any difficulty in refinancing it. It helps explain the rapid growth of the Chinese economy, led by an extraordinary level of public debt and high debt. With regard to the Brazilian economy, it gives an answer to the question that has been causing perplexity for over two decades: how can we explain that the country has been unable to grow sustainably and remains

\footnotetext{
${ }^{6}$ In Resende (2020) this article corresponds to Chapters 2 and 3 (pp. 53-102).
} 
stagnant without productivity gains for over three decades? (Resende, 2019a, 1, own translation)

But what would be the pillars of this new macro approach? The first is that fiduciary currency is government debt whose primary function is to be a unit of account, and that economic agents accept it because it is ultimately what allows them to settle their debts with the government.

The second pillar would follow from the first: the State has no financial constraints such as those faced by other economic agents - except as a self-imposed restriction, that is, politically decided and enforced by law. In fact, the State creates (or issues) its currency whenever it makes payments to the public and destroys it upon the receipt of payments. It follows from this reasoning that the macroeconomic role par excellence of taxes is not to finance the State, but to withdraw money (purchasing power) from the economy, preventing it from operating beyond full employment, which would generate inflation. In this sense, the restriction faced is on the availability of real resources (goods, services and mainly labor), not a financial (or fiscal) one.

The third pillar is the role of central banks in monetary policy, which is to determine exogenously the basic interest rate with open market operations when it buys and sells reserves/bonds. Central banks do not have the ability to control the creation of money by banks - bank money is endogenously created.

In the second article in the series, "Reasoning and Deficit Superstition" Resende rightly points out that laypeople do not accept that the government has no financial constraint because they basically interpret macroeconomics as similar to household finance. Meanwhile, mainstream economists continue to argue for austerity because of a deeply rooted misconception of what money is. Reflecting on the reasons why, Lara Resende takes up the ideas of the famed US economist Paul Samuelson, for whom the belief in the need for a balanced budget is a myth, but it serves the function to scare people in order to control their behavior. Without it, civilized life would be at risk. According to the author:

Paul Samuelson was one of the leading advocates of reasoning. As a macroeconomist, with his colleagues from the MIT Department of Economics in the second half of the last century, such as Robert Solow, Franco Modigliani, and others, he was a tireless critic of the quantity theory of money and fiscal dogmatism. However, Samuelson acknowledges that without control of public spending and rational resource allocation, the result is inefficiency and anarchy. This is the main issue in all the controversy surrounding the realization that the government has no financial constraint. Having no financial constraint does not mean that everything is allowed, that scarcity of resources does not exist and that the oppor-

\footnotetext{
${ }^{7}$ In Resende (2020) it corresponds to Chapter 4 (pp.103-117).
} 
tunity cost can be disregarded. Rather, it means that the relevant concern for public spending is quality, objective assessment of its costs and benefits, its ability to increase productivity and well-being. This is not, of course, an easy requirement to enforce, but it makes sense (Resende, 2019 b, 6, own translation).

Finally, in “Today's Brazil and Victorian Conservatism” (Resende 2019d) ${ }^{8}$, the author criticizes a second fallacy of mainstream economics widely present in the contemporary Brazilian debate: that public investments compete with private investments and make them unfeasible. It would be the so-called crowding-out effect. However, as Lara Resende points out, this "displacement" of private spending by public spending would only happen if the economy were in full employment. With unemployment and idle capacity, public spending would not displace private ones but would serve as a stimulus.

The responses to Lara Resende's interventions have begun with a heated debate between him and Edmar Bacha, another renowned Brazilian economist who also worked on elaborating and implementing the Real Plan. Bacha is a founding partner and director of the Institute of Economic Policy Studies "Casa das Garças", an important think-tank that brings together mainstream economists in Brazil. Bacha (2019) starts placing MMT on the "bottom floor of the American academy", superficially describing its mechanisms through the lens of one of its heterodox critics, Thomas Palley. By disregarding MMT's logical-theoretical linkages, he turns to the controversy raised by Lara Resende over the real burden of public debt, a topic that is recognized by the "popes of the profession in the USA" (Bacha, 2019, 2, own translation). According to Bacha, for developing countries like Brazil, in which the interest rate on public debt exceeds the rate of GDP growth, reaching primary surpluses is important so that the debt-to-GDP ratio - that is already high for these countries' standards - does not grow indefinitely.

Kfoury (2019) placed a similar argument on the wider fiscal space of developed economies. According to the author, if not well analyzed the ideas brought by Lara Resende would give ammunition for the heterodox to weaken the consensus for a more vigorous fiscal reform. For Kfoury (2019), the Brazilian Central Bank (BCB) has no unrestricted freedom to set the basic interest rate as it wishes, and experience shows that when it tried to artificially lower it - between 2011 and 2013 - there was an increase in inflation with a loss of anchoring expectations and the overheating of the economy.

On his turn, the current BCB Governor, Roberto Campos Neto, states that Lara Resende's ideas are part of a still embryonic work even for developed countries (Ribeiro et al., 2019). Following a similar path, to the BCB Deputy Governor of Economic Policy, although being a valid academic debate, it is less appropriate for practical economic policy, which requires fiscal consolidation and reforms. As he states:

${ }^{8}$ Which corresponds to Chapter 6 in Resende (2020). 
The main vectors by which fiscal policy matters for the CB's work are expectations, the medium and long-term trajectory of fiscal policy, public finances $[. .$.$] if fiscal policy manage to leave these deficits for surpluses it$ will manage to stabilize the public debt trajectory (Ribeiro et al., 2019, 1, own translation).

Critiques to MMT coming from Brazilian heterodox economists in the academia ${ }^{9}$ were stimulated after Lara Resende's articles, echoing the international debate among Post-Keynesians discussed in the previous section. Terra (2019), for instance, criticizes the chartalist approach and reinforces that trust is a necessary condition for an asset to perform as money. In this sense, tax collection is not a sufficient condition to ensure that this confidence is achieved. Money, according to Terra (2019), must be scarce in relation to its demand and this need for scarcity imposes a financial restriction on governments, which cannot banalize its production. Terra (2019) is then suggesting that a "confidence restriction" would come up at a certain point before the real resources restriction, preventing the use of expansionary fiscal policy as suggested by MMT.

Despite praising Lara Resende's public presentation of MMT and agreeing with some of its theoretical aspects, Paula (2019) considers it a simplistic theory. For the scholar, echoing Terra's (2019) critique, MMT disregards the importance of money in capitalist economies that goes beyond its function as a unit of account - e.g., money as a general form of wealth and, therefore, part of the agents' portfolio decisions. He also points out that the economy may face real restrictions before reaching full employment, such as bottlenecks in production, which would generate inflation. For him the absence of an explanation for inflation before full employment is one of the shortcomings of MMT. Paula (2019) also states that the theory ignores the asymmetries of the International Monetary System (IMS), in which peripheral countries find it difficult to issue foreign debt in their own currency, making their economic policy restrained by the assessment of risk and profitability from global investors. Therefore, MMT could not be generalized for those economies (Paula, 2019) ${ }^{10}$.

This line of argument centered on the hierarchy of currencies was already present in the works of Prates (2017) and Vergnhanini and De Conti (2018). For these authors, MMT underestimates the speculative nature of capital flows in the postBretton Woods era and the exchange rate volatility in open peripheral economies. The lynchpin of their argument is that in developing countries sitting at lower

\footnotetext{
${ }^{9}$ In the Brazilian academia some researchers had already been working on this theme before 2019. Besides Prates (2017) and Vergnhanini and De Conti (2017), that have been quite critical to MMT, researchers from the Federal University of Rio de Janeiro and the University of Campinas were already contributing to many aspects of the debate on MMT. Among others, one can cite Dos Santos (2005), Serrano and Pimentel (2017), Pimentel (2018) and Gerioni and Deos (2018).
}

10 Those critiques were already addressed in the previous section. 
levels in the international currency hierarchy $(\mathrm{ICH})^{11}$, the comparatively higher volatility of the exchange rate requires permanent interventions in the currency market by the monetary authority, which reinforces its interaction with policy rates and restrains policy autonomy ${ }^{12}$.

Lastly, we find one group of scholars who emphasize the conservatism in Lara Resende hidden behind the MMT facade. Vernengo (2019) states that Resende's theoretical pillars are essentially the New Classical Fiscal Theory of the Price Level (FTPL) coupled with endogenous money in a neo-Wicksellian sense. Summa and Serrano (2019) take a similar path and accurately add that Lara Resende's macro brings together mainstream theoretical assumptions, such as the existence of a potential output related to a natural interest rate and the impact of aggregate demand on growth only in the short term.

\section{CONCLUSIONS}

The spreading of MMT's ideas is helping in the task of breaking the siege of neoliberalism over Western countries, which has been lasting for almost 40 years independently of the parties which are in power, either conservatives or liberals even considering that there are slight differences between them. And it is important to consider that economists - the ones that have important positions either in governments, multilateral agencies, and also those which, day after day, give their opinions in traditional media - performed a crucial role in order to spread the neoliberal agenda as the only one possible and correct.

Ten years after the GFC, the disruptive effects of financial liberalization in the economies and societies all over the world are clear, with crucial effects in the political dimension - as we are watching democracies progressively deteriorating. There is an increasing perception that macroeconomic theory is flawed, as one can notice by reading pieces written by leading macroeconomists in the world, as Blanchard, Summers and Stiglitz, and taking into consideration that monetary policies are not up to the challenge of resuming growth in weak economies, in which the labor markets are still suffering either with high unemployment and/or with low quality and low paying jobs, we do need expansionary fiscal policy more than ever.

Regarding Brazil, the scenario has specific and important issues. In a first stage - which lasted during the last years of President Lula's second mandate (2007-2010)

\footnotetext{
${ }^{11}$ Currency hierarchy refers to the institutional structure of the International Monetary System organized around a national currency, called key currency, that fully functions as money in the international level (medium of payment, unit of account, and store of value), having the higher degree of liquidity. Around it stands other developed and developing nations' currencies that performs successively worse internationally (Andrade and Prates 2013; Prates 2017).

${ }^{12}$ Critiques also addressed in the second section.
} 
- the government successfully dealt with the spillover effects of the GFC in Brazil, using mainly the federal public banks as a way to boost the economy. In a second stage during President Rousseff's first mandate (2011-2014), the government decided to change direction and started to reduce fiscal stimuli to growth. Allegedly, it was time for the private sector to spend. But private investments didn't happen, the economy became increasingly weak and this was the perfect scenario for a political crisis that has led to the impeachment of President Rousseff. And here we are today, in a very dark scenario.

In January 2019, President Jair Bolsonaro took office. For the economy, the purpose was to deepen the liberal agenda in Brazil. This strong neoliberal policy is under the control of Ministry Paulo Guedes, for whom the main purpose is to shrink the size and limits of the State. According to Minister Guedes, public spending has always been 'guilty' in all crises that Brazil has faced throughout its history.

This was the scenario in which Lara Resende published his articles in 2019 in the main business paper in Brazil - Valor Econômico - contributing to creating small cracks in the consensus and to foster the debate on the best economic model. In those articles, echoing the discussions that have been going on abroad and inserting specific elements of the Brazilian situation, the author questions the foundations of mainstream economics. He does that by inserting some of MMT's central points but melted with mainstream ideas, as some critiques have accurately pointed out. So, he does not embrace MMT completely as he leaves aside, for instance, the analysis of financial fragility, an original contribution of Hyman Minsky that MMT incorporates. For Minsky and MMT, the role of the Central Bank goes beyond setting the basic interest rate, encompassing also the permanent task of regulating the financial system in order to reduce instability - including instability brought about by the speculative movements of foreign capital. But for Minsky and MMT this broaden role of Central Bank, in spite of being necessary, is far from sufficient. Lara Resende also left aside the key policy prescription of MMT, the Employer of Last Resort (ELR) - another Minskyan legacy for MMT, which reconnects macroeconomics with its main original concern - unemployment. The basic and bold idea of ELR is that the government should provide a job for everyone that is able and available to work and cannot find a job in the market, a crucial task for any economy and especially for the highly unstable peripheral economies.

As a final remark, one can say that Lara Resende did not consider the political aspects of MMT and full employment. For him, enlightenment and persuasion would be enough to destroy the balanced budget dogma. However, in order to avoid this oversimplification of the complex social reality, we should take Kalecki's lessons in consideration. According to this marvelous economist in a paper written in the 1940s, the idea that governments will keep economies running on full employment only because they know how to do that is naïve and misleading. For him, the ruling class can simply reject State intervention in the economy. They can disagree, specifically, with the type of intervention and can also dislike the social effects brought about by full employment. And it is very likely that this power bloc will find economists to 
declare, again and again, that a full-employment economy is an unbalanced one. So, besides a battle of ideas, there is also a political battle to be fought.

\section{REFERENCES}

Andrade, Rogério and Prates, Daniela. (2013) "Exchange rate dynamics in a peripheral monetary economy”. Journal of Post-Keynesian Economics, Vol 35 (3), 399-416.

Bacha, Edmar. (2019) “Comentários ao texto de André Lara Rezende, por Edmar Bacha”. In Valor Econômico. March 25th. https://valor.globo.com/brasil/noticia/2019/03/25/comentarios-ao-texto-de-andre-lara-resende-por-edmar-bacha.ghtml

Barbosa, Fernando, and Samuel Pessoa. (2014) “Desaceleração recente da economia.” In Sob a Luz Do Sol: Uma Agenda Para o Brasil, 15-30. Rio de Janeiro: Centro de Debate de Políticas Públicas.

Blanchard, Olivier. (2018) "On the future of macroeconomic models" In Rebuilding Macroeconomic Theory, Vol 34, Nos 1-2:43-54. Oxford: Oxford Review of Economic Policy.

Blanchard, Olivier, and Lawrence Summers. (2017) “Rethinking stabilization policy". In Back to the Future. Peterson Institution for International Economics. October 8.

Blanchard, Olivier, and Lawrence Summers. (2018) "Rethinking Stabilization Policy: Evolution or Revolution?" In NBER Working Paper n. 24179.

Dos Santos, Gustavo AG. (2005) “Uma Releitura das Finanças Funcionais” Rio de Janeiro: Tese de Doutorado, IE/UFRJ.

Epstein, G. (2019). “The institutional, empirical and policy limits of 'Modern Money Theory"”. Political Economy Research Institute Working Paper, number 481.

Gerioni, Enzo M. and Deos, Simone. (2018) “Minsky além da instabilidade financeira.” In XI Encontro Internacional da Associação Keynesiana Brasileira, 2018, Porto Alegre. Anais do XI Encontro da Associação Keynesiana Brasileira: "Desafios para a Economia Brasileira: uma perspectiva Keynesiana”. Vol 1.

Kalecki, Michael. (1997) “Os aspectos políticos do pleno emprego.” In: Miglioli, Jorge (org). Crescimento e Ciclo das Economias Capitalistas. São Paulo. Hucitec.

Keynes, John. (1971) “A treatise on money”. In: The Collected Writings of John Maynard Keynes Vol. $V$. London: Royal Economic Society.

Kfoury, Marcelo (2019) “Heterodoxia já quebrou o Brasil várias vezes.” In Valor Econômico. March 13 th.

Lavoie, Marc (2013). "The monetary and fiscal nexus of neo-chartalism: a friendly critique”. Journal of Economic Issues. Vol. XLVII No. 1 March 2013.

Lavoie, Marc (2019). “Modern Monetary Theory and post-Keynesian economics”, Real-World Economics Review, issue no. 89

Mankiw, Gregory. (2020). “A Skeptic's Guide to Modern Monetary Theory”. AEA Meeting. January.

Mesquita, Mario. (2014) "A política econômica do governo Dilma: a volta do experimentalismo". In: Sob a Luz do Sol: uma agenda para o Brasil, 3-14. Rio de Janeiro: Centro de Debate de Políticas Públicas.

Palley, Thomas (2015a). "Money, fiscal policy, and interest rates: a critique of Modern Money Theory," Review of Political Economy, 27(1) (2015), 1 - 27.

Palley, Thomas (2015b), “The critics of Modern Money Theory (MMT) Are Right,” Review of Political Economy, 27(1) (2015), 45 - 61.

Palley, Thomas (2019). "Macroeconomics vs Modern Money Theory: some unpleasant Keynesian arithmetic”. Post-Keynesian Association of Economics. Working Paper 1910, April 2019.

Paula, Luiz Fernando de. (2019) “Admirável mundo novo”. In Valor Econômico. April 1st.

Prates, Daniela. (2017) “Monetary sovereignty, currency hierarchy and policy space: a post-Keynesian approach” In IE-Unicamp Working Paper 315. 
Ribeiro, Alex, Versiani, Isabel and Lamucci, Sergio. (2019) "Para Campos, ideias de Lara são 'embrionárias"” In Valor Econômico. March 29th.

Resende, André L. (2019a) “A crise da macroeconomia.” In Valor Econômico. March 8th.

Resende, André L. (2019b) “Razão e superstição do déficit.” In Valor Econômico. April 18th.

Resende, André L. (2019c) "Liberalismo e dogmatismo.” In Valor Econômico. May 13th.

Resende, André L. (2019d) “Brasil de hoje e o eonservadorismo vitoriano.” In Valor Econômico. June 21st.

Serrano, Franklin and Pimentel, Kaio. (2017) “Será que 'acabou o dinheiro”? Financiamento do gasto público e taxas de juros num país de moeda soberana" In Revista de Economia Contemporânea. Vol 21. No. 2.

Stiglitz, Joseph. (2018) "Where modern macroeconomics went wrong." In Rebuilding Macroeconomic Theory, Vol 34, Nos 1-2. Oxford Review of Economic Policy.

Summa, Ricardo and Serrano, Franklin. (2019). "Dissenso ao Contrassenso do Novo Consenso: a Alternativa da Macroeconomia da Demanda Efetiva.” In IE-URFJ Discussion Paper 008.

Terra, Fabio. (2019) "Uma crítica pós-keynesiana ao MMT: a negligência do papel da confiança." In Valor Econômico. April th

Vergnhanini, Rodrigo and De Conti, Bruno. (2018) "Modern Monetary Theory: a criticism from the periphery." Brazilian Keynesian Review, Vol 3, No 2, 16-31.

Vernengo, Matías. (2019) "Lara-Resende and MMT in the Tropics." In Naked Keynesianism. March 12 th.

Vernengo, Matías and Caldentey, Esteban P. (2019). "Modern Money Theory (MMT) in the Tropics: Functional Finance in Developing Countries.” In Political Economy Research Institute Working Paper. No. 495.

Wray, L. Randall. (2003) Trabalho e moeda hoje: A chave para o pleno emprego e a estabilidade dos preços, 246. Rio de Janeiro: UFRJ/ Contraponto.

Wray, L. Randall. (2012) Modern Money Theory: A Primer on Macroeconomics for Sovereign Monetary Systems. Palgrave Macmillan.

Wray, L. Randall. (2015) Why Minsky Matters: an introduction to the work of a maverick economist. Princeton University Press.

Wray, L. Randall, Martin Watts, and William Mitchell. (2019) Macroeconomics. London: Macmillan International. 